\title{
A MESSAGE FROM MOSCOW
}

\author{
A. J. KUPZOW \\ 12 Mishin Street, FI. 32. Moscow A83
}

6th July 1966

A new scientific society of geneticists and plant and animal breeders has been organised in the U.S.S.R. by a congress which met in Moscow on 3 oth and 3 Ist May ig66.

Genetics and scientific breeding experienced a distressing situation in the U.S.S.R. during the period 1948-64. Under Lysenkoist domination classical genetics based on Mendel and Morgan was rejected, and scientific methods of plant and animal breeding such as inbreeding and the utilisation of interlinear hybrids were prevented. Instead of scientific biology there were spread all sorts of nonsense like the heritability of phenotypic variation and breeding by means of the "training" of young plants and animals, or the grafting ("vegetative hybridisation ") of an artificial allogamy in autogamous species.

Lysenkoism was one of the causes of a reduction of productivity in the agriculture of the U.S.S.R. Its methods of dictatorship in science and the persecution of all differently minded scientists were condemned by the 23 rd congress of the U.S.S.R. Communist party. The new genetic association is called upon to correct the mistakes of the past and to raise genetics and plant and animal breeding in the U.S.S.R. to the world scientific level. V. N. Stoletov spoke about these tasks.

A series of review lectures was presented as follows:

I. Results and perspectives of Genetics development (Lobashev, Astaurov, Dubinin).

2. Modern problems of genetics and the breeding of micro-organisms (Alikhanya).

3. Genetics and plant breeding (Zhukovsky).

4. The state and the prospects of maize breeding (Khadzhinov, Galleev).

5. Methods of breeding of high-yielding and high-quality varieties of the spring wheat (Mamontova).

6. Present problems of genetics and the breeding of animals (Belyaev).

7. Problems of distant hybridisation in plants (Tsitsin).

8. Genetics and medicine (Efraimson, Davidenkova, Pogosyants, Prokof'eva-Bel'gorskaya).

The congress stood in honour of the memory of those who lost their lives in the battle for genetic science, Vavilov, Karpechenko, Levitsky and others. A council of the new society was elected. It included Dubinin, Astaurov, Alikhanyan, Prokof'eva-Bel'govskaya and Sakharov. It elected the following officers of the Society

President: $\quad$ Boris L. Astaurov.

Vice-Presidents: A. Alikhanyan, Dmitrii K. Belyaev, Dmitrii D. Brezhnev and Nikolai V. Tsitsin.

The congress declared its unanimous wish to get rid most rapidly of the 
evil and nonsense of Lysenkoism, to revive genetics and scientific plant and animal breeding in the U.S.S.R., and to reach a high agricultural productivity in our native land.

Two distinguished Russian geneticists, Boris Astaurov and Nikolai Dubinin were elected members of the Academy of Sciences of the U.S.S.R. in July $\mathbf{r} 966$.

\section{Announcement \\ "GENETIKA": A NEW RUSSIAN JOURNAL}

A new Russian journal available in English

Translation into English of GENETIKA (U.S.S.R.) has been arranged on a continuing basis, and is available to libraries and individuals. The subscription rate is one cent per page, and the estimated price per year is $\$ 30$. Those interested in an annual subscription should submit $\$ 30$ and an adjustment will be made to conform to the one cent per page rate when the volume is completed. The first three numbers are available now and can be purchased individually for $\$ 6.00$ each for hard cover copies or $\$ 1.50$ each for microfiche. They can be ordered from Clearinghouse for Federal Scientific and Technical Information, Joint Publications Research Service, Tempo E., 6th and Adams Drive S.W., Washington, D.C.20442. Cheques should be made out to CFSTI/NBS.

Contents of Volume I, No. I ( 1965 ) in the Russian original is as follows:

\section{CONTENTS}

Genetics for the nation's economic prosperity

PAGE

Zhebrak, A. R. Gregor Mendel and the laws of heredity . . . 6

Vavilov, N. I. To what extent can Mendel's laws be universally applied to segregation in hybrids

Vavilov, N. I. A critical review of the present state of the genetic theory of plant and animal breeding

Zhuкovsky, P. M. Genetic and botanical regularities in the evolution of cultivated plants

Dubinin, N. P. The achievements of genetics-an aid to agriculture

AlikhaNyan, S. I. Genetics of microorganisms; advances in and prospects .

Sukhodoletz, V. V., Ilyina, T. S., and Alikhanian, S. I. Genetic mapping of $E$. coli $\mathrm{K}-\mathrm{I} 2$ thymineless mutants

Arman, I. P., and Kuznetsova, O. B. Recovery of $\nu$ - and UV-radiation induced premutational damage in yeast

Kameneva, S. V., Kalyaeva, E. S., and Alikhanian, S. I. Genetic studies of different quantitative requirements of thymine in $E$. coli $\mathrm{K}-\mathrm{I} 2$ thymineless mutants

GoldAt, S. Yu. The role of mutagenic factors in selection $A$. aureofaciens

Sidorov, B. N., Sokolov, N. N., and Andreyev, V. S. The mutagenic effect of ethyleneimine in a series of cell generations

Tupitsina, E. M. Studies on the nature of X-ray induced somatic mosaicism in heterozygote yellow and singed females of Drosophila melanogaster. .

RAPOPORT, J. A. Mutagenic effect of urethane in the gas state in presence of oxygen.

RApopt........ 130

RAPOPORT, J. A. Mutagenic effect of large volumes of diethyl sulfate gas . I42

Filıpova, L. M. Genetic effect of optically active compounds . . . $\quad$. 153 